\title{
Sow influence on neonatal survival: a special focus on colostrum
}

\author{
Hélène Quesnel ${ }^{1,2}$, Florence Gondret ${ }^{1,2}$, Elodie Merlot ${ }^{1,2}$, Florence Loisel $^{1,2}$ \\ and Chantal Farmer ${ }^{3}$ \\ IINRA, UMR 1348 PEGASE, F-35590 Saint-Gilles, France; ${ }^{2}$ Agrocampus Ouest, UMR 1348 PEGASE, \\ F-35000 Rennes, France; ${ }^{3}$ Agriculture and Agri-Food Canada, Dairy and Swine R \& D Centre, \\ Sherbrooke, Canada
}

The main cause of early postnatal deaths in piglets is hypothermia due to an inadequate intake of colostrum. Colostrum consumption is the outcome of complex interactions between the sow, the piglet, the litter and the environment. The sow may have an impact on many factors that are determinant for colostrum intake and chances of survival, such as piglet weight, maturity and vitality at birth, or within-litter variation in birth weight. Colostrum intake also depends on the ability of the sow to produce colostrum in sufficient quantity to fulfill the needs of the whole litter. Maternal stress during gestation may increase piglet morbidity and mortality up to weaning, presumably by affecting the ontogeny of the fetal immune system, but also IgG contents in colostrum and IgG transfer to newborn piglets. Ways to reduce neonatal mortality through maternal feeding during gestation are largely investigated. Feeding strategies generally failed to increase piglet birth weight but led to more promising results on piglet maturity and vitality at birth and on the acquisition of passive immunity. There is some evidence that maternal feeding during the peripartal period may influence both the quantity and the quality of colostrum; this needs however to receive further attention.

\section{Introduction}

Polytocous species like the pig produce a large number of offspring relatively undeveloped (Edwards 2002). Neonates have to compete for maternal resources, and the least able to compete will die shortly after birth. During the last few decades, a substantial increase in piglet mortality before weaning was observed in association with selection of sows to increase prolificacy and carcass lean merit. Piglet mortality has become a major source of economic loss in pig production and a social and ethical problem related to welfare concerns.

There is a large body of evidence that the main cause for piglet postnatal deaths is the lack of recovery from neonatal hypothermia, which is itself due to a low consumption of colostrum by newborn piglets (Edwards 2002, Le Dividich et al. 2005). Ultimately, hypothermia leads to starvation and crushing. Colostrum consumption and thus piglet survival are the outcome of complex interactions between the sow, the piglet, the litter and the environment (Figure 1). Colostrum intake depends on the ability of piglets to suckle quickly after birth. It is therefore influenced by piglet birth weight, maturity and vitality. Factors related to litter mainly involve size and within-litter variation in birth weight. Factors related to the sow involve farrowing 


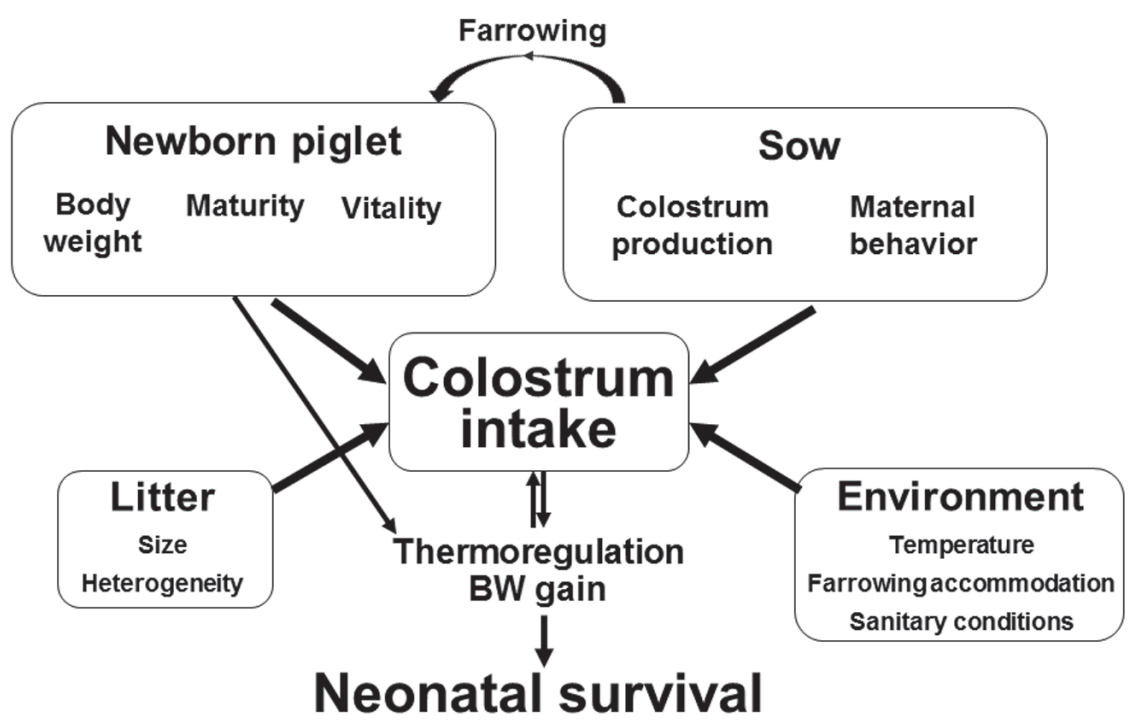

Fig. 1 Schematic representation of the main factors that influence colostrum intake, and thereby piglet survival.

duration, colostrum production, maternal behavior, and health status. Lastly, amongst factors related to environment, ambient temperature and farrowing accommodation could play a major role (for review see Baxter et al. 2013).

The purpose of the present review is to briefly update knowledge on the importance of colostrum for neonatal survival and to review the maternal influence on colostrum production and consumption. Clues to increase colostrum intake and neonatal survival via maternal feeding strategies will be discussed. Because survival during the first days after birth was not always recorded, survival performance up to weaning is also considered.

\section{Definition of colostrum}

Colostrum is the first secretion of the mammary gland; it is characterized by high concentrations of immunoglobulins (lg), and contains lower concentrations of lactose and lipids than milk. Lactogenesis starts at about 90 days of gestation in the sow. Lactogenesis I refers to the preparation of mammary tissue for the synthesis of milk components. Lactogenesis II, during which colostrum excretion occurs, starts shortly before parturition and lasts for approximately $24 \mathrm{~h}$ after the onset of parturition.

Colostrum intake by individual piglets can be estimated from the piglet weight gain during the first $24 \mathrm{~h}$ after birth. A prediction equation method allows this estimation (Devillers et al. 2004) and colostrum yield can be calculated as the sum of intakes by each piglet of the litter.

\section{Importance of colostrum in relation with neonatal survival}

Roles of colostrum for newborn piglets

Like many mammals, piglets at birth are abruptly exposed to a cold environment, being at least $10^{\circ} \mathrm{C}$ below their thermal neutrality. Thus, maintenance of homeothermia by activation 
of thermoregulatory mechanisms is pivotal. Unlike other mammals, the newborn piglet is devoid of thermogenic brown adipose tissue. Moreover, compared to most other mammals, its overall lipid content is low (less than $2 \%$, Seerley \& Poole 1974). Hepatic and muscle glycogen thus represent the main stores provisioning heat-producing tissues with energy. In the French Large White breed, selection for reduced carcass fatness has lowered fat and liver glycogen contents (Canario et al. 2007), therefore exacerbating the problem for newborn piglets. Energy stores are completely depleted within 12 to $17 \mathrm{~h}$ after birth in the absence of colostrum intake (Theil et al. 2011). Colostrum is thus essential for early post-natal survival as it will be a substitute to glycogen in providing energy for thermoregulation. Colostrum ingestion also assists the newborn piglets in their physiological adaptation after birth by stimulating energy metabolism and thermoregulatory mechanisms (Herpin et al. 2005) and the development of the gastrointestinal tract (Xu et al. 2002).

Colostrum is also crucial in providing the newborn piglet with passive immunity. At birth, the pig is devoid of $\mathrm{Ig}$, and its immune system has not been stimulated by antigens (Rooke \& Bland 2002). Porcine colostrum is rich in IgG that provide systemic immunity. IgG concentrations in colostrum quickly decrease within $24 \mathrm{~h}$ after the onset of farrowing and are low in milk. Porcine colostrum also contains IgA, which play an essential role in protecting the intestinal mucosa from pathogens, thereby preventing neonatal diarrhea and reducing neonatal mortality. Colostrum also contains immune cells and immunomodulatory factors that play a role in the response to pathogens and that may help maturation of the piglet's own immune system (Salmon et al. 2009).

\section{Relations between colostrum intake and piglet birth-to-weaning survival}

The relations between colostrum intake during the first $24 \mathrm{~h}$ after birth and piglet survival and health were recently reviewed (Quesnel et al. 2012) and hence will be only briefly summarized in the present paper. Individual colostrum intake during the first $24 \mathrm{~h}$ after birth averages 250-300 g (Devillers et al. 2007, Quesnel 2011), and ranges from 0 to more than $700 \mathrm{~g}$. A low consumption of colostrum (below $200 \mathrm{~g}$ ) considerably decreases piglet survival until weaning (Devillers et al. 2011). At high colostrum intakes ( $>400 \mathrm{~g}$ ), a positive correlation is also observed between colostrum consumption and survival rate during the first day after birth (Theil \& Lauridsen 2012). With regard to immunity, plasma IgG concentrations in piglets at $24 \mathrm{~h}$ of age increase with colostrum intake (Klobasa et al. 1981). Because colostrum IgG concentrations fall rapidly, piglets born later during farrowing may consume a colostrum poorer in IgG and thus have lower plasma IgG concentrations at $24 \mathrm{~h}$ than first-born piglets (de Passillé et al. 1988, Foisnet et al. 2011). However, beyond a certain amount of colostrum ingested (about 200 g), plasma IgG concentrations do not increase further (Devillers et al. 2011) so that even a relatively low consumption of colostrum can provide passive immunity to piglets. In conclusion, a suboptimal consumption of colostrum increases the risk of neonatal mortality and may affect the immune status and susceptibility to infections until weaning.

\section{Sow influence on piglet maturity and colostrum consumption}

Maternal effect on birth weight and maturity

Birth weight is the most important factor in successful recovery from postnatal hypothermia (Kammersgaard et al. 2011) and a critical factor for preweaning survival (Roehe \& Kalm 2000, Tuchscherer et al. 2000, Baxter et al. 2008). The relation between birth weight and piglet survival however does not exist across breeds. For example, Meishan piglets have a better 
survival rate than piglets from European breeds although they are lighter at birth, because they possess greater lipid stores and have improved hepatic metabolic ability (Fainberg et al. 2012). Within a given genotype, Leenhouwers et al. (2002) reported that piglets with a higher genetic merit for survival had increased relative organ weights, cortisol concentrations, and glycogen and fat reserves. Therefore, both birth weight and maturity may be predisposing factors for neonatal losses, as previously suggested (van der Lende et al. 2001).

One of the reasons for the effect of birth weight on survival is its major influence on colostrum intake. An overall increase in colostrum intake of $28 \mathrm{~g}$ per $100 \mathrm{~g}$ increase in birth weight was reported (Devillers et al. 2007). Colostrum intake by piglets was also shown to be negatively related with within-litter variation in birth weight (Devillers et al. 2007). Consistently, an increased within-litter variation in birth weight was identified as a negative factor for piglet survival (Milligan et al. 2002, Damgaard et al. 2003).

\section{Maternal effect on vitality at birth: influence of the farrowing process}

Piglet vitality at birth involves the ability to quickly reach the teat and to extract colostrum. Vitality immediately after delivery is related to the process of fetal maturation (inherent vitality) and to the process of parturition and the associated risk of hypoxia. The degree of intra-partum hypoxia plays a major influence on latency to suckle and thus on survival (Herpin et al. 1996). Hypoxia increases with increasing farrowing duration, litter size, and late position in the birth order (Herpin et al. 1996).

\section{Colostrum production}

Colostrum yield varies greatly among sows, from less than $1.5 \mathrm{~kg}$ to more than $6.0 \mathrm{~kg}$, with an average value of $3.5 \mathrm{~kg}$ for the $24 \mathrm{~h}$ after the onset of parturition (Figure 2). The first step in identifying the factors affecting colostrum yield is to establish whether sow or piglet characteristics are most important. Colostrum is freely available during the first 12 hours after parturition (de Passillé \& Rushen 1989) and regular suckling by piglets to maintain lacteal secretion and initiate lactation is not required until 16-24 hours post-partum (Atwood et al. 1995, Theil et al. 2006). Consistently, litter size and litter weight do not influence colostrum yield or piglet growth during early lactation (Devillers et al. 2007, Figure 2). Furthermore, piglets which were bottle-fed with colostrum during the first $24 \mathrm{~h}$ after birth and kept in a similar environment to sow-reared piglets, had a voluntary intake exceeding $450 \mathrm{~g} / \mathrm{kg}$ birth weight, which was twice the average consumption of sow-reared piglets (Devillers et al. 2004). Together, these data indicate that the sow likely produces less colostrum than could be consumed by the litter.

Colostrum production is under hormonal control. The prepartum peak of prolactin is essential for lactogenesis in swine and is brought about by the drop in progesterone concentrations (Farmer et al. 1998). A very low production of colostrum ( $\sim 1 \mathrm{~kg})$ was associated with delays in progesterone decrease and in prolactin increase during the prepartum period (Foisnet et al. 2010). Furthermore, a reduced growth rate and an increased mortality rate in early lactation were reported in piglets from sows that had greater circulating concentrations of progesterone immediately after farrowing (de Passillé et al. 1993, Quesnel et al. 2013a). We also recently reported that sows with a lower colostrum yield $(<3 \mathrm{~kg}$ ) had more stillborn piglets than other sows (on average 1.8 vs. 0.9) and tended to have a slower process of parturition during early parturition, with longer birth interval between the first and the third piglet (95 vs 71 min, Quesnel 2011). Since many hormones involved in parturition are also involved in lactogenesis, one may wonder whether abnormalities in the endocrine status of sows in late pregnancy might have detrimental effects on parturition and on colostrum production. 


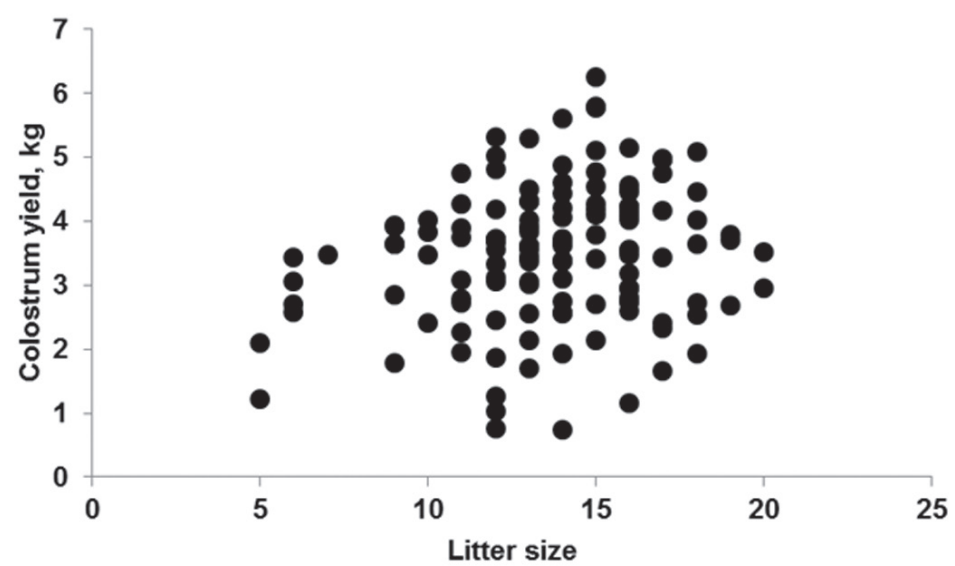

Fig. 2 Estimated colostrum yield during the $24 \mathrm{~h}$ after the onset of parturition in relation to litter size. Data was obtained from 134 crossbred Landrace $x$ Large White sows at the INRA herd (Saint-Gilles, France). Colostrum yield was not correlated with the number of piglets nursed $(r=0.19, P>0.10$, Quesnel, unpublished data).

One factor which could influence colostrum yield is mammary development. Indeed, a greater mammary development can lead to a greater milk yield (Head et al. 1991) and, even though it was never specifically looked at, it is likely that this could also hold true for colostrum production. Moreover, there is a correlation between the size of a mammary gland (either in terms of weight or DNA) and its milk yield, as estimated by the average daily gain between days 1 and 24 of lactation for the piglet suckling that teat (Nielsen et al. 2001). Nevertheless, it is not known if this is solely related to differences in mammary development already present at farrowing or if it is also linked with the vigor of the piglets massaging the udder. Recent data also indicate that mammogenesis can affect milk yield and, potentially, colostrum yield. When teats were either blinded or not in first lactation, teats which were previously used produced more milk (based on weight gain of piglets from days 2 to 14 of lactation) and were more developed on day 17 of the second lactation (Farmer et al. 2012a). Furthermore, piglets suckling teats which were previously used had significantly greater weight gains as early as from days 2 to 4 of lactation, whereas piglets suckling on teats which were not previously used showed behaviors indicative of a greater hunger level on day 3, but not on day 10, of lactation (Farmer et al. 2012a). Together, this information suggests that mammary development may have an impact on colostrum production.

\section{Influence of maternal stress}

Reproductive sows are often exposed to behavioral (shipping and moving to a new environment, food frustration, social stress due to grouping with unfamiliar conspecifics or competition for the access to feeders) or physical (thermal stress, leg disorders) stressors during gestation. Studies using limited numbers of animals did not report any effect of prenatal stress on neonatal mortality (Jarvis et al. 2006, Couret et al. 2009a, b). Using slightly greater numbers of animals, Tuchscherer et al. (2002) found that repeated restraint during the last third of gestation increased piglet mortality from 6 to $14 \%$ during the suckling period. Mortality was probably increased because of the greater susceptibility of suckling piglets to diseases (morbidity was increased from 12 to $28 \%$ in this study), but maternal behavior can also be altered, increasing the risk of crushing the offspring (Ringgenberg et al. 2012). On the other hand, maternal stress does 
not affect birth weight. Social stress during mid- or late-gestation (Jarvis et al. 2006, Couret et al. 2009a, b), repeated snaring during late gestation (Tuchscherer et al. 2002) and rough handling during mid-gestation (Lay et al. 2008) did not affect piglet birth weight. The only study investigating the factors affecting piglet vitality and latency before the first milk intake did not show any influence of prenatal stress on these traits (Otten et al. 2007).

A major consequence of maternal stress for piglet survival is probably related to the acquisition of passive immunity. Heat during the last week of pregnancy or behavioral stressors during the last third of pregnancy decreased circulating IgG concentrations in neonatal piglets (MachadoNeto et al. 1987, Tuchscherer et al. 2002). This may result from a lower IgG content in maternal colostrum (Machado-Neto et al. 1987) or from an altered intestinal transfer of IgG from the gut to the circulation in neonates. In late gestation, a transient increase in maternal glucocorticoids due to maternal stress may mimic the natural cortisol variations which occur around parturition and accelerate gut closure, thus leading to impaired immunoglobulin acquisition after birth (Machado-Neto et al. 1987, Bate et al. 1991). Maternal restraint and social stressors during gestation were also shown to affect maturation of the piglet's immune system (Tuchscherer et al. 2002, Couret et al. 2009a, b), but the consequences of these alterations are probably more important for the post- than pre-weaning period.

\section{Feeding strategies to increase neonatal survival}

Influence of maternal feeding during gestation on piglet development

Level of feeding, diet composition and specific nutrients provided to the sow during pregnancy may influence fetal growth and the development of specific tissues in offspring (such as muscle fibers which are essentially formed prenatally and affect postnatal muscle growth), and thus maturity at birth. The roles of selected nutrients and amino acid status are reviewed in the present proceedings (Bazer et al. 2013, Wu et al. 2013) and will therefore not be detailed here. Nevertheless, some examples will be given with respect to predisposing factors for postnatal losses.

Increasing feed supply. When compared with sows fed at levels routinely used for pregnancy, an increased feed supply $(+30 \%$ to $+100 \%$ ) during early to mid-gestation ( 3 - d 32, Hoving et al. 2011; d 0 - d 50, Bee 2004; d 25 - d 50, Dwyer et al. 1994, Gatford et al. 2003, Nissen et al. 2003, McNamara et al. 2011) and up to day 85 of gestation (d 50 - d 80; Dwyer et al. 1994, McNamara et al. 2011; d 45 - d 85, Cerisuelo et al. 2009) did not affect birth weight or within-litter variation in birth weight, even in situations where sows in the "plus feed" treatment gained more BW during the experimental period (Hoving et al. 2011). In these studies, litter size at birth varied from 9.9 to 14.2 total born, and 9.5 to 12.5 born alive regardless of treatments. Dwyer et al. (1994) observed that doubling sow feed intake $(5 \mathrm{~kg} / \mathrm{d})$ during the second or third quarters of pregnancy tended to increase the number of muscle fibers in the offspring, with a positive effect on postnatal growth rate. Although an increased maternal nutrition during pregnancy may increase the insulin:glucose ratio in maternal blood (Gatford et al. 2003), the exact mechanisms by which overnutrition during pregnancy may affect the formation of secondary muscle fibers in developing fetuses, remain unclear. However, more recent studies produced conflicting results with greater (Gatford et al. 2003), similar (Nissen et al. 2003) or smaller (Cerisuelo et al. 2009) numbers of fibers in the muscle of progeny with maternal overfeeding. The possible impacts of these strategies on fat content and muscle glycogen reserves have not been investigated. When feed allowance was increased $(+780 \mathrm{~g} / \mathrm{d})$ in the last 15 days of gestation, there was again no effects on birth weight but an improvement in 
piglet vitality during the first hours of postnatal life (Quiniou 2005), maybe because the highest feed allowance made sow farrowing easier in this study.

Fat supply. Feeding more energy in the form of added fat during the last quarter of pregnancy did not affect piglet birth weight, total litter birth weight, or piglet survival (Coffey et al. 1987, van der Peet-Schwering 2004). Piglets born from sows fed soybean oil (rich in omega-6 fatty acids) had a higher viability score at birth than the progeny from sows fed tuna oil (rich in omega-3 fatty acids) when farrowings were induced on day 113 (Rooke et al. 1998).

Dietary protein and amino acid supply. Feeding extra protein with greater digestible amino acids during early gestation ( $\mathrm{d} 3$ to $\mathrm{d} 32$ ) did not influence average birth weight of piglets when compared with a control diet (Hoving et al. 2011). Moreover, feeding a high protein:low carbohydrate diet throughout pregnancy resulted in lower $(-14 \%)$ average birth weights than a control diet, for the same litter size. This was likely due to maternal energy deficit in treated compared with control sows, so that maternal nutrients were partitioned in favor of maternal anabolism (Metges et al. 2012). This feeding regimen also reduced body fat (less adipocyte number) and total fiber number in skeletal muscles of the newborn piglets (Rehfeldt et al. 2012). A number of experiments also dealt with dietary supplementation of specific amino acids. Many studies showed a positive effect of L-arginine supplementation $(25 \mathrm{~g} / \mathrm{d})$ from day 14 to day 28 of gestation on the number of fetuses or piglets born alive, without any detrimental effects on individual weight and within-litter variation in birth weight (see review by Le Floch et al. 2012). As the nitrogenous precursor of nitric oxide, a vasodilator and angiogenic factor, and polyamines, which are key regulators of protein synthesis and angiogenesis, L-arginine enhances placental growth and regulates multiple metabolic pathways. Positive effects were also observed on embryonic growth when $20 \mathrm{~g}$ /day of L-arginine was added to the diet of sows from either day 15 to day 29, day 30 to day 44 or day 15 to day 44 of gestation (Novak et al. 2012). When supplementary L-arginine was fed from day 77 up to term, birth weight was unaltered but the coefficients of variation of birth weight of total born piglets were reduced by 3\%, when compared with control sows (Quesnel et al. 2013b). This effect was significant in litters of less than 17 total born but not in larger litters, which suggests that a physiological limit, presumably uterine capacity, cannot be overcome by nutritional supplementation in those large litters.

Conflicting results were reported using top-dressing with L-carnitine, a derivative from lysine and methionine that may affect the insulin-like growth factor (IGF) system, during gestation. When L-carnitine was fed throughout gestation, individual fetal weight was not affected on day 57 (Waylan et al. 2005) but it tended to be greater on day 70 (Brown et al. 2008). Providing L-carnitine as a premix during gestation did not affect the number of piglets born and born alive but resulted in greater piglet birth weight (Eder et al. 2001, Ramanau et al. 2002) or increased the number of piglets at birth while decreasing their individual weights (Ramanau et al. 2004).

\section{Influence of maternal feeding on mammary gland development}

Mammary development occurs at distinctive periods in swine. The periods from 90 days of age until puberty and throughout the last third of gestation are the two stages of rapid mammary accretion (Sørensen et al. 2002) where feeding regimes could have an impact on potential colostrum yield. For the purpose of the current review, the focus will be on feeding of the late-pregnant sow.

Head \& Williams (1991) reported that when manipulating the body composition of gilts by changing their protein and energy intakes during gestation, fat gilts produced less milk (7 l/d) than lean gilts $(9 \mathrm{l} / \mathrm{d})$ of the same body weight due to alterations in the number of mammary alveolar cells. Weldon et al. (1991) also showed that increasing dietary energy (5.76 vs. 10.5 
Mcal ME/d) as of day 75 of gestation decreased mammary parenchymal weight by $21 \%$ and total parenchymal DNA by $23 \%$ on day 105 of gestation. On the other hand, increasing protein intake (330 vs. $216 \mathrm{~g} \mathrm{CP/d}$, Weldon et al. 1991) or lysine intake (4, 8 or $16 \mathrm{~g} / \mathrm{d}$ ) had no effects on mammogenesis. Crenshaw et al. (1989) reported that diet deprivation followed by overallowance during the growing, finishing and gestation phases increased sow milk yield and modulated the relative expression of casein $\beta$ in mammary tissue. Using that same feeding regimen in the growing-finishing period (Farmer et al. 2012b) or in the gestation period only (Farmer et al. unpublished data) had, however, no beneficial effect on mammary development at the end of gestation. It is apparent that the ideal feeding strategy to maximize mammary development in late-gestating sows has yet to be established.

A recent report indicated that nutrition of sows in gestation and lactation can also affect mammary development of their offspring at puberty. Indeed, when $10 \%$ flaxseed was fed to sows from day 63 of gestation until weaning, their female offspring showed an increase in mammary parenchymal tissue weight expressed as a percentage of body weight $(0.37 \%$ vs. $0.27 \%$ ) at puberty (Farmer \& Palin 2008). This programming effect in swine on lactating ability of the offspring opens new avenues in terms of development of maternal feeding strategies to enhance mammogenesis and potential milk/colostrum yield.

\section{Influence of maternal feeding during the periparturient period on colostrum production}

The literature on the influence of maternal feeding on colostrum yield is scarce, probably because this trait cannot be measured easily. Most recent findings deal with the impact of the level and source of dietary fat and fiber. Hansen et al. (2012) and Theil \& Lauridsen (2012) compared five "transition" diets given during the last week of gestation. These diets contained either $3 \%$ animal fat (standard diet) or $8 \%$ fat from various origins and provided various proportions of medium- and long-chain fatty acids. Colostrum yield was increased by diets containing coconut or sunflower oil (490 g/piglet/d), and was further increased by the diet containing fish oil and octanoic acid (550 g/piglet/d), when compared with the standard diet or the diet containing $8 \%$ fish oil (460 g/piglet/d). In contrast, Papadopoulos et al. (2009) observed no beneficial effect of feeding sunflower oil compared with fish oil during the last week of gestation on piglet growth and survival. Dietary CLA from day 108 of gestation onward negatively affected colostrum intake by piglets (409 vs $463 \mathrm{~g} / \mathrm{d}$ ) and survival rate during the first week of lactation (82 vs 92\%, Theil \& Lauridsen 2012).

Feeding high-fiber diets during part of gestation or during the transition period increased piglet weight gain by $14 \%$ during the first 5 or 7 days after birth (Guillemet et al. 2007, Oliviero et al. 2009). Since isocaloric fiber-rich diets tended to increase prolactin concentrations around parturition (Farmer et al. 1995, Quesnel et al. 2009), the beneficial effect on piglet growth could be related to greater circulating concentrations of prolactin and increased production of colostrum. Our recent findings, however, did not support this assumption, because feeding sows a high-fiber diet $(7.9 \%$ vs. $3.3 \%$ crude fiber) during the transition period had no effect on prolactin concentrations or colostrum yield (Loisel et al. 2013). Nevertheless, it increased piglet survival during lactation and colostrum intake by piglets weighing less than $900 \mathrm{~g}$. This effect could not be related to vitality at birth, farrowing duration or sow endocrine or metabolic status, suggesting that it may be related to the beneficial effect of dietary fiber on sow maternal behavior.

The influence of maternal feeding on colostrum composition was more investigated than its effect on colostrum yield. Lipids and immunoglobulins are the two components which are most sensitive to nutritional changes. Supplementing the diet of sows with fat during late pregnancy increases total lipids in colostrum and may increase lipid accretion in piglets, but seems to have 
no significant impact on piglet weight and survival (for review see Farmer \& Quesnel 2009). Many studies considered various ingredients that presumably have immunomodulating effects (e.g., fish oil, fermented liquid feed, mannan oligosaccharides). They reported a significant increase in concentrations of IgG, IgA and/or IgM in colostrum, but in only a few cases were there positive effects on plasma IgG concentrations or body weight gain of piglets (Krakowski et al. 2002, Bontempo et al. 2004). Unexpectedly, sows fed a high-fiber diet during late pregnancy had lower IgA concentrations in colostrum and milk (Loisel et al. 2013). Consequences of such nutritional strategies on piglet survival need to be further investigated.

\section{Conclusion}

Neonatal survival largely depends on adequate colostrum intake by newborn piglets and it is therefore essential to increase the amount and quality of colostrum ingested by piglets. Feeding strategies applied to the sow during gestation generally failed to increase piglet birth weight. Vitality and viability, on the other hand, could be influenced by supplementary feeding of specific fatty acids or amino acids. The use of ingredients with potential immunomodulatory effects increased concentrations of immunoglobulins in colostrum and in piglet plasma, yet the impact of such ingredients on neonatal survival needs to be investigated in farms. Lastly, there is some evidence that maternal feeding during the peripartal period may influence both the quantity and the quality of colostrum; this definitely needs to receive further attention.

\section{References}

Atwood C, Toussaint JK \& Hartmann PE 1995 Assessment of mammary gland metabolism in the sow. II. Cellular metabolites in the mammary secretion and plasma during lactogenesis II. Journal of Dairy Research $\mathbf{6 2}$ 207-220.

Bate LA, Ireland W, Connell BJ \& Grimmelt B 1991 Development of the small intestine of piglets in response to prenatal elevation of glucocorticoids. Histology and Histopathology 6 207-216.

Baxter EM, Jarvis S, D'Eath RB, Ross DW, Robson SK, Farish M, Nevison IM, Lawrence AB \& Edwards SA 2008 Investigating the behavioural and physiological indicators of neonatal survival in pigs. Theriogenology $69773-783$.

Baxter EM et al. 2013 Determining piglet survival. In Control of Pig Reproduction IX, pp 129-144. Eds H Rodriguez-Martinez, Soede NM \& W Flowers. Context Products Ltd.

Bazer F et al. 2013 Roles of selected nutrients on development of the porcine conceptus during pregnancy. In Control of Pig Reproduction IX, pp 159-174. Eds H Rodriguez-Martinez, Soede NM \& W Flowers. Context Products Ltd.

Bee G 2004 Effect of early gestation feeding, birth weight, and gender of progeny on muscle fiber characteristics of pigs at slaughter. Journal of Animal Science $\mathbf{8 2}$ 826-836.

Bontempo V, Sciannimanico D, Pastorelli G, Rossi R, Rosi F \& Corino C 2004 Dietary conjugated linoleic acid positively affects immunologic variables in lactating sows and piglets. Journal of Nutrition 134 817-824.
Brown KR, Goodband RD, Tokach MD, Dritz SS, Nelssen JL, Minton JE, Higgins JJ, Lin X, Odle J, Woodworth JC \& Johnson BJ 2008 Effects of feeding L-carnitine to gilts through day 70 of gestation on litter traits and the expression of insulin-like growth factor system components and L-carnitine concentration in fotal tissues. Journal of Animal Physiology and Animal Nutrition 92 660-667.

Canario L, Père MC, Tribout T, Thomas F, David C, Gogué J, Herpin P, Bidanel JP \& Le Dividich J 2007 Estimation of genetic trends from 1977 to 1998 of body composition and physiological state of Large White pigs at birth. Animal 1 1409-1413.

Cerisuelo A, Baucells MD, Gasa J, Coma J, Carrión D, Chapinal N \& Sala R 2009 Increased sow nutrition during midgestation affects muscle fiber development and meat quality, with no consequences on growth performance. Journal of Animal Science 87 729-739.

Coffey MT, Yates JA \& Combs GE 1987 Effects of feeding sows fat or fructose during late gestation and lactation. Journal of Animal Science 65 1249-1256.

Couret D, Jamin A, Kuntz-Simon G, Prunier A \& Merlot E 2009a Maternal stress during late gestation has moderate but long-lasting effects on the immune system of the piglets. Veterinary Immunology and Immunopathology 131 17-24.

Couret D, Prunier A, Mounier AM, Thomas F, Oswald IP \& Merlot E 2009b Comparative effects of a prenatal stress occurring during early or late gestation on pig immune response. Physiology and Behavior 98 498-504. 
Crenshaw JD, Park CS, Swantek PM, Keller WL \& Zimprich RC 1989 Lactation response of gilts to a phased feeding regimen designed to induce compensatory growth. Journal of Animal Science $\mathbf{6 7}$ (Suppl. 2)107-108.

Damgaard LH, Rydhmer L, Løvendahl P \& Grandison K 2003 Genetic parameters for within-litter variation in piglet birth weight and change in within-litter variation during suckling. Journal of Animal Science 81 604-301.

De Passillé AMB \& Rushen J 1989 Using early suckling behavior and weight gain to identify piglets at risk. Canadian Journal of Animal Science 69 535-544.

De Passillé AMB, Rushen J \& Pelletier G 1988 Sucking behaviour and serum immunoglobulins levels in neonatal piglets. Animal Production 47 447-456.

De Passillé AMB, Rushen J, Foxcroft GR, Aherne F \& Schaefer A 1993 Performance of young pigs: relationship with periparturient progesterone, prolactin and insulin of sows. Journal of Animal Science 71 179-184.

Devillers N, van Milgen J, PrunierA \& Le Dividich J 2004 Estimation of colostrum intake in the neonatal pig. Animal Science 78 305-313.

Devillers N, Farmer C, Le Dividich J \& Prunier A 2007 Variability of colostrum yield and colostrum intake in swine. Animal 1 1033-1041.

Devillers N, Le Dividich J \& Prunier A 2011 Influence of colostrum intake on piglet survival and immunity. Animal 5 1605-1612.

Dwyer CM, Stickland NC \& Fletcher JM 1994 The influence of maternal nutrition on muscle fiber number development in the porcine fetus and on subsequent postnatal growth. Journal of Animal Science 72911 917.

Eder K, Ramanau A \& Kluge H 2001 Effect of L-carnitine supplementation on performance parameters in gilts and sows. Journal of Animal Physiology and Animal Nutrition 85 73-80.

Edwards SA 2002 Perinatal mortality in the pig: environmental or physiological solutions? Livestock Production Science 78 3-12.

Fainberg HP, Bodley K, Bacardit J, Li D, Wessely F, Nigel P. Mongan NP, Symonds ME, Clarke L \& Mostyn A 2012 Reduced Neonatal Mortality in Meishan Piglets: A Role for Hepatic Fatty Acids? PLoSONE 7 e49101.

Farmer C \& Palin M-F 2008 Feeding flaxseed to sows during late-gestation and lactation affects mammary development but not mammary expression of selected genes in their offspring. Canadian Journal of Animal Science 88 585-590.

Farmer C \& Quesnel H 2009 Nutritional, hormonal and environmental effects on colostrum in sows. Journal of Animal Science 87(Suppl. 1) 56-65.

Farmer C, Robert S, Matte JJ, Girard CL \& Martineau GP 1995 Endocrine and peripartum behavioral responses of sows fed high-fiber diets during gestation. Canadian Journal of Animal Science 75 531-536.

Farmer C, Robert S \& Rushen J 1998 Bromocriptine given orally to periparturient or lactating sows inhibits milk production. Journal of Animal Science 76 750-757.

Farmer C, Palin M-F, Theil PK M. T. Sorensen MT \& Devillers N 2012a Milk production in sows from a teat in second parity is influenced by whether it was suckled in first parity. Journal of Animal Science $\mathbf{9 0}$ 3743-3751.

Farmer C, Palin M F \& Martel-Kennes Y 2012b Impact of diet deprivation and subsequent over-allowance during prepuberty. Part 1. Effects on growth performance, metabolite status, and mammary gland development in gilts. Journal of Animal Science 90 863-871.

Foisnet A, Farmer C, David C \& Quesnel H 2010 Relationship between colostrum production by primiparous sows and sow physiology around parturition. Journal of Animal Science 88 1672-1683.

Foisnet A, Farmer C, David C \& Quesnel H 2011 Farrowing induction induced transient alterations in prolactin concentrations and colostrum composition in primiparous sows. Journal of Animal Science $\mathbf{8 9}$ 3048-3059.

Gatford KL, Ekert JE, Blackmore K, De Blasio MJ, Owens JA, Campbell RG \& Owens PC 2003 Variable maternal nutrition and growth hormone treatment in the second quarter of pregnancy in pigs alter semitendinosus muscle in adolescent progeny. British Journal of Nutrition 90 283-293.

Guillemet R, Hamard A, Quesnel H, Père M-C, Etienne M, Dourmad J-Y \& Meunier-Salaun M-C 2007. Dietary fibre for gestating sows: Effects on parturition progress, behaviour, litter and sow performance. Animal 1 872-880.

Hansen AV, Lauridsen C, Sørensen MT, Bach Knudsen KE \& Theil PK 2012. Effects of nutrient supply, plasma metabolites, and nutritional status of sows during transition on performance in the next lactation. Journal of Animal Science 90 466-480.

Head RH \& Williams IH 1991 Mammogenesis is influenced by pregnancy nutrition. In Manipulating Pig Production, edn III, p 33. Eds ES Batterham. Werribee, Australasian Pig Science Association.

Head RH, Bruce NW \& Williams IH 1991 More cells might lead to more milk. In Manipulating Pig Production, edn III, p 76. Eds ES Batterham. Werribee, Australasian Pig Science Association.

Herpin P, Le Dividich J, Hulin JC, Fillaut M, De Marco F \& Bertin J 1996 Effects of the level of asphyxia during delivery on viability at birth and early postnatal vitality of newborn pigs. Journal of Animal Science 74 2067-2075.

Herpin P, Louveau I, Damon M \& Le Dividich J 2005 Environmental and hormonal regulation of energy metabolism in early development of the pig. In Biology of Metabolism in Growing Animals, pp 353-374. Eds DG Burrin and $\mathrm{H}$ Mersmann. Amsterdam: Elsevier Limited.

Hoving LL, Soede NM, van der Peet-Schwering CMC, Graat EAM, Feitsma H \& Kemp B 2011 An increased feed intake during early pregnancy improves sow body weight recovery and increases litter size in young sows. Journal of Animal Science 89 3542-3550. 
Jarvis S, Moinard C, Robson SK, Baxter E, Ormandy E, Douglas AJ, Seckl JR, Russell JA \& Lawrence AB 2006 Programming the offspring of the pig by prenatal social stress: Neuroendocrine activity and behaviour. Hormones and Behavior 49 68-80.

Kammersgaard TS, Pedersen LJ \& Jørgensen E 2011 Hypothermia in neonatal piglets: Interactions and causes of individual differences. Journal of Animal Science 89 2073-2085.

Klobasa F, Werhahn E \& Butler JE 1981 Regulation of humoral immunity in the piglet by immunoglobulins of maternal origin. Research in Veterinary Science 31 195-206.

Krakowski L, Krzyzanowski J, Wrona Z, Kostro K. \& Siwicki AK 2002 The influence of nonspecific immunostimulation of pregnant sows on the immunological value of colostrum. Veterinary Immunology and Immunopathology 87 89-95.

Kusina J, Pettigrew JE, Sower AF, White ME, Crooker BA \& Hathaway MR 1999 Effect of protein intake during gestation on mammary development of primiparous sows. Journal of Animal Science 77 925-930.

Lay DC, Kattesh HG, Cunnick JE, Daniels MJ, McMunn KA, Toscano MJ \& Roberts MP 2008 Prenatal stress effects on pig development and response to weaning. Journal of Animal Science 86 1316-1324.

Le Dividich J, Rooke JA \& Herpin P 2005. Review: Nutritional and immunological importance of colostrum for the newborn pig. Journal of Agricultural Science 143 469-485.

Leenhouwers JI, Knol EF \& van der Lende T 2002 Differences in late prenatal development as an explanation for genetic differences in piglet survival. Livestock Production Science 78 57-62.

Le Floc'h N, Gondret F, Matte JJ \& Quesnel H 2012 Towards amino acid recommendations for specific physiological and patho-physiological states in pigs. Proceedings of Nutrition Society 71 425-432.

Loisel F, Farmer C, Ramaekers P \& Quesnel H 2013 [Effect of high dietary fibre in late gestating sows on colostrum yield and piglet performance during lactation]. Journées de la Recherche Porcine 45 177-182.

McNamara LB, Giblin L, Markham T, Stickland NC, Berry DP, O'Reilly JJ, Lynch PB, Kerry JP \& Lawlor PG 2011 Nutritional intervention during gestation alters growth, body composition and gene expression patterns in skeletal muscle of pig offspring. Animal 5 1195-1206.

Machado-Neto R, Graves CN \& Curtis SE 1987 Immunoglobulins in piglets from sows heat-stressed prepartum. Journal of Animal Science 65 445-455.

Metges CC, Lang IS, Hennig U, Brüssow KP, Kanitz E, Tuchscherer M, Schneider F, Weitzel JM, SteinhoffOoster A, Sauerwein H et al. 2012 Intrauterine growth retarded progeny of pregnant sows fed high protein:low carbohydrate diet is related to metabolic energy deficit. PLoSOne 7 e31390.

Milligan BN, Fraser D \& Kramer DL 2002 Within-litter birth weight variation in the domestic pig and its relation to pre-weaning survival, weight gain, and variation in weaning weights. Livestock Production Science 76 181-191.
Nielsen OL, Pedersen AR \& Sørensen MT 2001 Relationships between piglet growth rate and mammary gland size of the sow. Livestock Production Science 67 273-279.

Nissen PM, Danielsen VO, Jorgensen PF \& Oksbjerg N 2003 Increased maternal nutrition of sows has no beneficial effects on muscle fiber number or postnatal growth and has no impact on the meat quality of the offspring. Journal of Animal Science 81 3018-3027.

Novak S, Paradis F, Patterson JL, Pasternak JA, Oxtoby K, Moore HS, Hahn M, Dyck MK, Dixon WT \& Foxcroft GR 2012 Temporal candidate gene expression in the sow placenta and embryo during early gestation and effect of maternal Progenos supplementation on embryonic and placental development. Reproduction Fertility Development 24 550-558.

Oliviero C, Kokkonen T, Heinonen M, Sankari S \& Peltoniemi O 2009 Feeding sows with high fibre diet around farrowing and early lactation: Impact on intestinal activity, energy balance related parameters and litter performance. Research in Veterinary Science 86 314-319.

Papadopoulos GA, Maes DGD, van Weyenberg S, van Kempen TATG, Buyse J \& Janssens GPJ 2009 Peripartal feeding strategy with different $n-6: n-3$ ratios in sows: effects on sow's performance, inflammatory and periparturient metabolic parameters. British Journal of Nutrition 101 348-357.

Quesnel H 2011 Colostrum production by sows: variability of colostrum yield and immunoglobulin G concentrations. Animal 5 1546-1553.

Quesnel H, Meunier-Salaün MC, Hamard A, Guillemet R, Etienne M, Farmer C, Dourmad JY \& Père MC 2009 Dietary fiber for pregnant sows: Influence on sow physiology and performance during lactation. Journal of Animal Science 87 532-543.

Quesnel H, Farmer C \& Devillers N 2012 Colostrum intake: influence on piglet performance and factors of variation. Livestock Science 145 105-114.

Quesnel H, Ramaekers P, van Hees H \& Farmer C 2013a Short communication: relations between peripartum concentrations of prolactin and progesterone in sows and piglet growth in early lactation. Canadian Journal of Animal Science $\mathbf{9 3}$ in press.

Quesnel H, Quiniou N, Roy H, Lottin A, Boulot S \& Gondret F 2013b [Impact of supplementation of dextrose before insemination and arginine during the third part of gestation on within-litter variation of piglet weight at birth]. Journées de la Recherche Porcine 45 183-188.

Quiniou N 2005 Effect of feed allowance during late gestation on farrowing progress, piglets' vitality and lactation performance]. Journées de la Recherche Porcine 37 187-194.

Ramanau A, Kluge H, Spilke J \& Eder K 2002 Reproductive performance of sows supplemented with dietary L-carnitine over three reproductive cycles. Archiv für Tierernaehrung 56 287-296.

Ramanau A, Kluge H, Spilke J \& Eder K 2004 Supplementation of sows with L-carnitine during pregnancy and lactation improves growth of the piglets during the suckling period through increased milk 
production. Journal of Nutrition 134 86-92.

Rehfeldt C, Lefaucheur L, Block J, Stabenow B, Pfuhl R, Otten W, Metges CC \& Kalbe C 2012 Limited and excess protein intake of pregnant gilts differently affects body composition and cellularity of skeletal muscle and subcutaneous adipose tissue of newborn and weanling piglets. European Journal of Nutrition 51 151-165.

Ringgenberg N, Bergeron R, Meunier-Salaün M-C \& Devillers N 2012 Impact of social stress during gestation and environmental enrichment during lactation on the maternal behavior of sows. Applied Animal Behaviour Science 136 126-135.

Roehe R \& Kalm E 2000 Estimation of genetic and environmental risk factors associated with pre-weaning mortality in piglets using generalized linear mixed models. Animal Science 70 227-240.

Rooke JA \& Bland IM 2002 The acquisition of passive immunity in the new-born piglet. Livestock Production Science 78 13-23.

Rooke JA, Bland IM \& Edwards SA 1998 Effect of feeding tuna oil or soybean oil as supplements to sows in late pregancy on piglet tissue composition and viability. British Journal of Nutrition 80 273-280.

Salmon H, Berri M, Gerdts V \& Meurens F 2009 Humoral and cellular factors of maternal immunity in swine. Developmental and Comparative Immunology 33 384-393.

Seerley RW \& Poole DR 1974 Effect of prolonged fasting on carcass composition and blood fatty acids and glucose of neonatal swine. Journal of Nutrition $\mathbf{1 0 4}$ 210-217.

Sørensen MT, Sejrsen K \& Purup S 2002 Mammary gland development in gilts. Livestock Production Science 75 143-148.

Theil P \& Lauridsen C 2012 Improving piglet survivability by altered maternal nutrient supply for transition sow. In Book of Abstracts of the $63^{\text {rd }}$ Annual meeting of the European Association for Animal Production, p 43. Bratislava, Slovakia.

Theil PK, Sejrsen K, Hurley WL, Labouriau R, Thomsen B \& Sørensen MT 2006 Role of suckling in regulating cell turnover and onset and maintenance of lactation in individual mammary glands of sows. Journal of Animal Science 84 1691-1698.
Theil PK, Cordero G, Henckel P, Puggaard L, Oksbjerg N \& and Sørensen MT 2011 Effects of gestation and transition diets, piglet birth weight, and fasting time on depletion of glycogen pools in liver and 3 muscles of newborn piglets. Journal of Animal Science $\mathbf{8 9}$ 1805-1816.

Tuchscherer M, Puppe B, Tuchscherer A \& Tiemann U 2000 Early identification of neonates at risk: traits of newborn piglets with respect to survival. Theriogenology 54 371-388.

Tuchscherer M, Kanitz E, Otten W \& Tuchscherer A 2002 Effects of prenatal stress on cellular and humoral immune responses in neonatal pigs. Veterinary Immunology and Immunopathology 86 195-203.

van der Lende T, Knol EF \& Leenhouwers JI 2001 Prenatal development as a predisposing factor for perinatal losses in pigs. In Control of Pig Reproduction, edn VI, pp 247-261. Eds RD Geisert, H Niemann \& C Doberska. London: The Society for Reproduction and Fertility.

van der Peet-Schwering CMC, Kemp B, Binnendijk GP, den Hartog LA, Vereijken P FG \& Verstegen MWA 2004 Effects of additional starch or fat in lategestating high nonstarch polysaccharide diets on litter performance anal glucose tolerance in sows. Journal of Animal Science 82 2964-2971.

Waylan AT, Kayser JP, Gnad DP, Higgins JJ, Starkey JD, Sissom EK, Woodworth JC \& Johnson BJ 2005 Effects of L-carnitine on fetal growth and the IGF system in pigs. Journal of Animal Science 83 1824-1831.

Weldon WC, Thulin AJ, MacDougald OA, Johnston LJ, Miller ER \& Tucker HA 1991 Effects of increased dietary energy and protein during late gestation on mammary development in gilts. Journal of Animal Science 69 194-200.

Wu G 2013 Maternal and fetal amino acids metabolism in gestating sows. In Control of Pig Reproduction IX, pp 185-198. Eds H Rodriguez-Martinez, Soede NM \& W Flowers. Context Products Ltd.

Xu RJ, Sangild PT, Zhang YQ \& Zhang SH 2002 Bioactive compounds in porcine colostrum and milk and their effects on intestinal development in neonatal pigs. In Biology of the Intestine of Growing Animals, pp 169192. Eds R Zabielski, PC Gregory and B Weström. Amsterdam: Elsevier Science. 